\title{
DEVELOPMENT OF RESPONSIBILITY OF STUDENT YOUTH AS ONE OF THE UNIVERSITY TASKS
}

\author{
Tetyana Rozvadovska \\ Postgraduate Student, National Pedagogical Dragomanov University, Ukraine \\ e-mail: rozvadovskatet@gmail.com, orcid.org/0000-0003-0631-4417
}

\section{Summary}

The article presents analysis and characterization of definitions of responsibility in scientific research and responsibility defined as an important property of the personality. Author presented the pertinences between responsibility, freedom of choice, values and morality. The influence of such skills as reflection and empathy on the development of responsibility is getting determined. The author analyzed psychological - pedagogical features of student age, which include: the formation of self - identity and worldview, search for their place in life, the formation of the value core of the individual, recognition of their own involvement in socially positive changes. Student age is defined as a sensitive period for the development of responsibility. It is established that the social activity of student youth, involvement in solving social problems, contributes to the development of responsibility and recognition of their own importance in the implementation of socially positive transformations in the community. Service - Learning is interpreted as one of the approaches to the development of responsibility of student youth. Service-Learning is characterized as an effective way to involve student youth in active participation in community life by helping to solve problems relevant to it, which contributes to a sense of self-importance, and consequently, the development of responsibility. The results of scientific researches on the influence of Service - Learning on the development of responsibility of student youth are generalized.

Keywords: community, education, responsibility, service - learning, service - learning in higher education, sensitive period, student, upbringing.

\section{DOI: https://doi.org/10.23856/3865}

\section{Introduction}

Current Ukraine is characterized by changes that affect all aspects of society life, especially the upbringing of children and youth. Development of responsibility of student youth is very relevant, because it is known that student youth is active participants in changes of society. In this age self-consciousness, social consciousness of the individual and self-identification are getting formed. The realities of today require the development of students' conscious attitude to the development of Ukrainian society and social relations, the ability to make decisions in unusual situations and be responsible for them. That's why one of the priority tasks of university is searching for new ways for development of responsibility of student youth. Successful solution of the problem of developing the responsibility of student youth depends on understanding the essence of this concept and the importance of responsibility in the life of each personality. During searches and implementing new approaches to the development of responsibility, it is necessary to consider psychological and pedagogical peculiarity of student age. Therefore, the aim of the article was to analyze the concept of "responsibility", generalize the psychological and pedagogical features of student youth, justify student age as a sensitive period for the development of responsibility and characterize Service - Learning as one of the approaches to forming and developing student responsibility. 


\section{Definition of responsibility}

Definition of responsibility is quite multifaceted and it is considered in different aspects. The Enlightenment Age philosopher Kant I. (1994) identified responsibility with the absolute moral law, which was embodied in the human conscience. It means a person's ability to be independent in their actions and decisions, in his opinion. Independent decisions and actions are possible under the condition of freedom of choice. Freedom of choice is possible only in the absence of external pressure during committing or not committing of acts. In this case only, the personality can take responsibility for their decisions and actions. If personality is under pressure, there is a transfer of responsibility from oneself to the person or institution that exerts that pressure. The responsibility of the personality is closely linked to personal freedom, the ability to make free decisions (Frankl, 1990). Responsibility cannot be an externally imposed duty, but a desire to respond to another person's need (From, 1994). In committing a responsible act, a person is guided by his inherent morality. Morality, in turn, presupposes the existence of such virtues as honesty, prudence, justice, love of neighbor, etc. Responsibility is considered as a moral quality of the personality that controls his actions. In Manuylov E. (2014) opinion, decision-making and responsible action depends on the values and morality of the personality. Personal values should include responsibility, knowledge of its essence and significance in the life of each person, recognition of responsibility as one's own value. Responsibility considered as a function of ensuring the possibility of the future, as well. Nowadays, humanity is characterized by the development of innovative technologies that affects global changes in the environment. Personality must be aware of his own responsibility for these changes, the consequences of which will be felt by all mankind (Jonas, 1979, as cited in Stančiene, 2010). To be responsible means to see the coherence between the present and the future, to realize the importance of your own influence on the future.

The development of responsibility is facilitated by the ability to empathize with another person, to put oneself in the place of that person, to establish emotional contact with him. Having such a skill allows a personality to take responsibility for another, help him solve certain difficulties or problems. Chaplak Y. (2018) in his research substantiates empathy as a factor in altruistic behavior, the desire to help others, and therefore an understanding of one's own responsibility for the well-being of others. Responsibility belongs to the existential needs of personality, which is manifested in altruistic love and the desire to take care of important beings and people, which means to take responsibility for their well-being (From, 1994). Responsibility is getting developed consistently, from making a choice and action until its rethinking. It is the rethinking of one's actions that contributes to responsible behavior in the future (Savchin, 1996). Rethinking is possible through the analyzing of one's own behavior and the behavior of others, the implementation of reflection. Reflection helps to anticipate the consequences of own actions for oneself and for others. Based on the implementation of such an analysis, the personality is able to predict further developments, the reaction of others to his action, which allows you to make responsible decisions and perform responsible actions. Andriievskyi, I. (2020) in his investigation, substantiates reflection as a factor in the development of personal responsibility. In Vashchenko G. (1999) opinion, one of the priority tasks of a pedagogue is the upbringing of a responsible person. He has emphasized that the personality is responsible for the creation of the society in which he is in and his own future in it. That is why a personality from an early age should be involved in social activities in community.

Taking into account analysis of the concept of "responsibility", responsibility is defined as an integral property of the individual, which includes knowledge about the nature of 
responsibility, the presence of moral qualities and values, the ability to analyze and predict the consequences of actions and be ready to take responsibility.

Note that the responsibility is formed in the process of interaction of the personality with society, the assimilation of social norms, rules and values and manifests itself as an awareness of its importance in social change. A responsible personality is always an active participant in the social life of his community.

\section{Student age as a sensitive period for the development of responsibility}

Student age, first of all, is characterized by the acquisition of certain independence. It is facilitated by separation from parents and the acquisition of skills for future professional activities. Admission to the university and choosing a profession contributes to the process of self-identification of a young person. According to Erikson, E. (2000) at this age the individual experiences a crisis of "identity" and the formation of the "core" of the individual. Accordingly, it is important to involve young people in various social institutions, communities and making them aware of their involvement in them. At this age, values are determined, life is getting planned, social roles are getting accepted and appropriate patterns of behavior are being formed. Also, a young person is experiencing an existential crisis, looking for his place in life; there is curiosity interest in moral and ethical issues, which contributes to the formation of such traits as kindness, loyalty, generosity, justice, etc. The central problem is the search for an individual personal attitude to social reality (Slobodchikov, V. I., Isae, E. I., 2000). During this period that the moral consciousness of the individual is formed, the development of value orientations and the establishment of worldview, civic position takes place (Zebrowska, M., 1975).

Student youth, as a rule, are an active participant in society life, the activity of young people is facilitated by their social environment, the university community, the availability of time to combine professional and personal growth. Involving student youth in solving social problems and acute issues allows them to discover their own potential, to feel their belonging to the community. According to the theory of Maslow, A. (1943), involvement in solving socially acute issues and problems of the community, allows to meet such a need as belonging and self-actualization that contributes to the formation of the value core of the individual. It is important that in addition to meeting the needs of student youth, there is also meeting the needs of the object of activity. That allows young people to feel their own importance in socially positive changes, their responsibility for them, forms an active civic position. Interacting with different categories of the society, student youth learn different social experiences. Consciousness of their significance in the community life and the environment is crucial for the development of the responsibility of student youth. Because this consciousness allows understanding our own responsibility for changes that occur or do not occur in the community, and, consequently, the personality is an active participant, not just a spectator (Bekh, I.D., 1995).

Analysis shows that the student age is a sensitive period for the development of responsibility of student youth. In the student age following qualities are getting formed: self-identity, individual's values, morality, worldview, etc. There is an assimilation of new social roles, search for meaning in life, the formation of independence, professional development, self-realization etc. Development of responsibility acquires special significance as one of the main regulators of behavior. Therefore, universities need to create appropriate conditions, paying attention to the search and development of new methodological principles and effective educational-methodological support for upbringing responsibility of student youth. In addition, universities should 
pay attention to the development of opportunities for student youth to solve social problems, participate in social initiatives both within the university and outside it.

\section{Service - learning as one of the way for development of responsibility of students' youth}

Worldwide, in particular in North and South America, as well as in Western Europe, such an educational approach as Service - Learning is widely used. In recent years, this educational approach is gaining popularity in Eastern Europe, including Ukraine. Service - Learning, as a rule, involves the transformation of academic knowledge into a professional skill through the solution of problems relevant in the community. There are four main features of Service Learning, that includes: comprehensive and quality education; development of initiatives aimed at meeting the real needs of the community; active participation of students in the planning, development and evaluation of Service - Learning project; combining educational content with practice (Furco, A et al., 2017). The generalization of approaches to the definition of criteria of Service - Learning by Butin, D. V. (2003) allows to define it as a credit part of the training course, that is aimed not only at acquiring academic knowledge, but also gaining practical experience through participation in organized community service as a response for community needs. By reflecting on Service - Learning project, students evaluate and understand the content of the course and strengthen their sense of civic responsibility. So, Service - Learning activates the social activities of student youth, which is defined as one of the means of developing responsibility, through awareness of their own involvement in the community, as well as a sense of self-importance in the changes taking place around. In the research of Brozmanova, G. A. \& Kubelakova, M. (2017) present the impact of Service - Learning on the development of social and personal responsibility of students youth. During two semesters, students of various specialties had the opportunity to attend a specially designed course related to project management and activities for the benefit of others. The first semester included theoretical studying, and in the second, students had to identify the needs of the community and create activities that would meet the identified needs. The research in the experimental and control groups confirmed that students in the experimental group became more sensitive to community problems and felt responsible to the community, aware that their actions have an impact on the environment, and the community in particular. In addition, students who were involved in Service - Learning are more aware of their responsibilities than those students who were not involved in Service - Learning. Thus, Service - Learning includes: a clearly organized process of combining studying and service; the close relationship between curriculum and community service; service - the answer to the real need / problem of the community. The institutionalization of Service - Learning in universities promotes the activity of student youth, their involvement in solving problems of the community. Through participation in the life of the community, student youth feel their own significance, which contributes to the development of responsibility.

\section{Conclusions}

Based on the analysis, responsibility is defined as an integral property of the individual, which includes knowledge about the essence of responsibility, the presence of moral qualities and values, the ability to analyze and predict the consequences of actions and be ready to take responsibility for them. Student age is defined as a sensitive period of responsibility of student youth, due to the inherent psychological and pedagogical features of this age such as: the formation of self-identity, worldview, finding their place in life, becoming a core personality, 
consciousness of their involvement in socially positive changes etc. For the harmonious development of responsibility in the student age, universities need to pay attention to the organization of various types of activities that involve interaction with the community. One of the types of such activities is the introduction of Service - Learning in the university. Promising areas of work are the generalization of the results of experimental work on the impact of involving student youth in mentoring on the development of their responsibility.

\section{References}

Andriyevs 'ky j, I. (2020). Refleksiya yak faktor rozvy`tku osoby`stisnoyi vidpovidal'nosti majbutnix faxivciv medy 'chnoyi sfery' $v$ procesi profesijnogo stanovlennya [Reflection as a factor for the development of the personal responsibility of future medical specialist in the process of their professional establishment]. Naukovy`j visny`k Khersons kogo derzhavnogo universy 'tetu. Seriya Psy xologichni nauky`. Kherson. 2 (2020). 7-14. DOI: 10.32999/ ksu2312-3206/2020-2-1 [in Ukrainian].

Bekh, I. D. (1995). Vid voli do osoby stosti. [From will to personality]. Kyiv: Ukraine-Vita. [in Ukrainian].

Brozmanova, G. A., Kubelakova, M. (2017). Service-learning and development of social and personal responsibility. IV JIAS Conference of researchers on service-learning. Buenos Aires. 82-88. [in English].

Butin, D. V. (2003) Of What Use Is It? Multiple Conceptualizations of Service Learning Within Education. Teachers College Record. Vol. 105, № 19. 1674-1692. [in English].

Chaplak Ya. V. (2018). Problema empatiyi v psy xologiyi ta yiyi vazhly vist u profesijnomu stanovlenni psy xologa. [The problem of empathy in psychology and its importance in the professional development of a psychologist]. Psychological Journal. 5 (15). 24-39. DOI: 10.31108/2018vol12iss2 [in Ukrainian].

Erikson E. (2000). Detsvo i obshhestvo [Childhood and Society]: Ed. 2nd, rev. and add. / lane Alekseev A.A. SPb.: "Letnij sad". [in Russian].

Frankl, V. (1990). V bor be za smy'sl. [Man in search of meaning]. M: Progress. [in Russian]. Fromm, E. (1994). Escape from Freedom. New York: Henry Holt \& Company Inc. [in English]. Furco, A., Anderson, B., Hirt, L., López, I., Maruyama, G., Matthews, P.H., Schulzetenberg, A., Wilder, S.O. (2017). Measuring Service - Learning quality: developing best practices instrument and algorithm. IV JIAS Conference of researchers on service-learning. Buenos Aires. 30-39. [in English].

Kant, I. (1994). Kritika chistogo razuma [Critique of pure reason]. M: Misl. [in Russian]. Manuylov, E. (2014). Problema vidpovidal nosti osoby stosti v konteksti morali [Problem of personal responsibility in the context of morality]. Visny $k$ Nacional nogo universy tetu "Yury `dy 'chna akademiya Ukrayiny`imeni Yaroslava Mudrogo», 4, 29-34. [in Ukrainian].

Maslow, A. H. (1943). A Theory of Human Motivation. Retrieved from http://citeseerx.ist.psu. edu/viewdoc/download? doi=10.1.1.318.2317\&rep=rep1\&type=pdf [in English].

Savchin, M. (1996). Vidpovidal 'nist': smy slovy j pry ‘ncy'p moty vacijnoyi regulyaciyi povedinky 'osoby 'stosti [Responsibility: the semantic principle of motivational regulation of personality behavior]. Pedagogika i psy xologiya. № 1, 10-18. [in Ukrainian].

Stančiene, D. M. (2010). Social Ethics of Hans Jonas: the responsibility principle. LOGOS, 62, 65-72. Retrieved from URL http://www.litlogos.eu/L62/Logos_62_065_072_Stanciene.pdf [in Lithuanian]. 
Slobodchikov, V. I., Isae, E. I. (2000). Osnovy` psixologicheskoj antropologii. Psixologiya razvitiya cheloveka: razvitie sub "ektivnoj real nosti v ontogeneze: Uchebnoe posobie dlya vuzov [Fundamentals of psychological anthropology. Psychology of human development: the development of subjective reality in ontogenesis: A textbook for universities]. M.: Shkol naya pressa. [in Russian].

Vashchenko, G. (1999). Vy'xovannya voli i xarakteru - pidruchny k dlya pedagogiv [Upbringing of will and character - a textbook for teachers]. Kyiv: Shkolyar. [in Ukrainian].

Zebrowska, M. (Ed.) (1975). Psychologia rozwojowa dzieci i młodzieży [Developmental psychology of children and youth]. Warsaw: State Scientific Publishers. [in Polish]. 